\title{
Protection of Places With high Concentration of People: Metro
}

\section{MARTA BLAHOVÁ \& ONDŘEJ ZIMEK}

Abstract: The article deals with the issue of protection of places with a large concentration of people with a focus on the metro system in the Czech Republic and worldwide. The following sections are devoted to the comparison of metro systems in the world, the use of the metro as an object of civil protection, including food, water, air, energy, etc. Furthermore, the text deals with the list and description of real incidents that have occurred or may occur in the metro, such as fires, floods, terrorist attacks, etc., including security measures and emergency services exercises.

Key words: Security measures, rescue service exercises, history of the metro in Prague, places of high concentration of persons, metro protection system, flood control measures, fire prevention, terrorist attack, metro facilities.
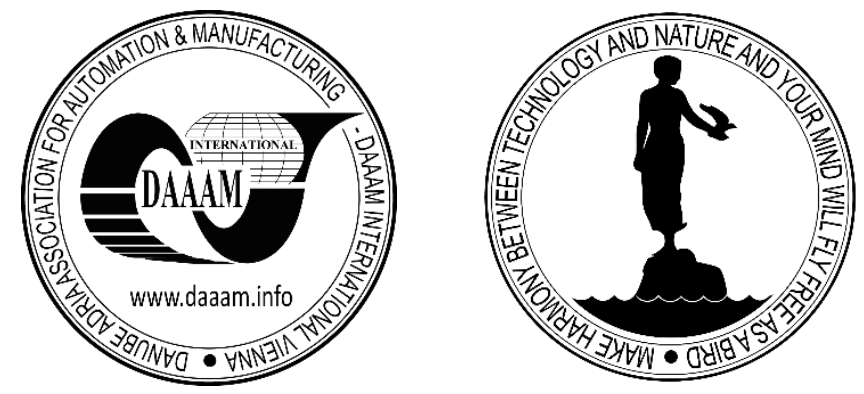

Authors' data: Blahova, M[arta]; \& Zimek, O[ndra] * Fakulta aplikované informatiky - Univerzita Tomáše Bati ve Zlíně, Nad Stráněmi 4511, 76005 Zlín, CZ, m6_blahova@utb.cz,zimek@utb.cz

This Publication has to be referred as: Blahova, M[arta] \& Zimek, O[ndrej] (2019). Protection of Places with High Concentration of People: Metro, Chapter 24 in DAAAM International Scientific Book 2019, pp.287-300, B. Katalinic (Ed.), Published by DAAAM International, ISBN 978-3-902734-24-2, ISSN 1726-9687, Vienna, Austria

DOI: $10.2507 /$ daaam.scibook.2019.24 


\section{Introduction}

The theme of this article is to protect places with a large concentration of people: the metro. Given the recent events and the increasing number of terrorist attacks, this is a topical issue. The aim of the article is to get as much information as possible about the security measures of the metro system, to find out what are the current trends in the security of the metro system in the Czech Republic but also in the world and to compare these measures. The main aim of the article is to create well-arranged and, as far as possible, comprehensive material on the metro system, in particular the risks, including their enumeration, and how they can be prevented through safety measures, or at least as effectively as possible.

\section{Metro in Europe and the world}

The metro system in the world differs mainly in the security used. Some states use turnstiles, while others have canceled turnstiles, elsewhere in the world we find tubes or safety barriers that prevent people from accidentally or deliberately falling into the track. However, even this kind of security is not always $100 \%$. There are known cases, for example from China, where a crowded person did not get into the metro wagon in time and remained trapped between the already closed tube door and the metro door.

\section{London Underground}

The London Underground is the oldest in the world and was put into operation on January 10, 1863. It can carry around 4 million passengers a day. Currently, there are 292 stations on 12 lines with a total operating length of 452 kilometers. Some routes are underground, others subsurface, routes outside the city center usually run on the surface. [1] The most obvious difference from the metro in the Czech Republic is the provision of newer London metro stations with safety walls. The main reason for their use was perhaps somewhat surprising. Reportedly it was primarily to reduce the air flow caused by emergency fans, which are activated in case of fire. The secondary function of the safety walls was the function of the barrier against the fall of passengers into the track. Another difference is the turnstiles at the entrances to the metro, which were canceled in the Prague metro. [2]

\section{Paris Metro}

In Paris we find one of the oldest underground railways in the world. Plans to build date back to 1845, the first line was put into operation on July 19, 1900 on the occasion of the World Exhibition and Olympic Games. Paris Metro has a very dense network of lines, the largest in the world. It has two lines more than the London Underground, 14 lines of 370 stations. The Paris Metro system has a total of 213 kilometers of tracks and can carry around 5 million passengers a day. [3] There are two types of trains on the lines, classic metal wheels and rubber tires, thanks to which the trains are able to handle a greater slope of the route. Like some London Underground lines, the Paris Metro has security walls. 
Some lines have been run without driver, everything is automatic, there are optical sensors to ensure that no one gets stuck in the closed metro door. As in the London Underground, there are turnstiles at the Paris Metro.

\section{New York subway}

For the first time, passengers in New York City traveled the subway on October 27, 1904. The New York Metro is one of the busiest subway systems in the world, carrying up to 6 million passengers a day. On routes with a total length of $368 \mathrm{~km}$ there are 26 lines with 468 stations. Some sources indicate different numbers because of the high number of connected and interchange stations that someone may or may not count. The subway in New York is less specific, as it operates 24 hours a day, seven days a week. After the attacks of September 11, 2001, it was forbidden to take pictures at the stations and the metro, now it is again permitted, police officers carry out random baggage checks without giving any reason. Trains are equipped, among other things, with a safeguard against sudden disability of the driver or his sudden death. It ensures that the train does not continue to travel. [4]

\section{Metro as an object of civil protection}

The metro system is not only used to transport residents, but also to hide or evacuate them in the event of an emergency as a so-called permanent pressure-resistant shelter. These are 'permanent protective areas in underground parts or detached underground objects'. [5] It is able to protect sheltered persons against all sorts of hazards such as pressure waves, penetrating radiation, radioactive contamination, light and heat radiation, chemical and biological weapons . [6]

From the metro system to the highest protection shelters in Prague include:

- all metro stations of line A;

- metro station line B from Nové Butovice to Českomoravská;

- metro station line $\mathrm{C}$ from Roztyly to Háje and from Vltavská to Holešovice.

The system of permanent pressure-resistant shelters does not include vestibules located just below the surface.

\section{Metro protection system}

"The metro protection system is a complex of premises and equipment inside and outside metro stations and tunnels used to hide and evacuate Prague residents in emergencies." [7] The metro protection system includes only mined stations and mined track tunnels with technological background because they resist direct hit by an aboveground nuclear bomb explosion. [8] The tunnel built by excavation has a lower resistance to the pressure wave. The protection system therefore does not include the entire section from the Florenc station to Kačerov and all surface and aboveground parts of the metro. Underground protection systems include underground garages at Dejvická station and garages at Vltavská station. It is a completely self-sufficient system. 
Blahova, M. \& Zimek, O.: Protection of Places with High Concentration of People: ...

In addition to weapons of mass destruction, radiation, and the effects of chemical contamination, the system can also protect against floods and floods caused by a rupture of the Vltava cascade. The height of this storm wave is estimated 17 meters above the normal river level.

The metro protection system can accommodate approximately 300,000 people, after the completion of the D-line and the inner metro circuit, the capacity is expected to increase to approximately 600,000 . The hiding time is only 72 hours, even though the original intention was 21 days. However, given the financial situation of the then Czechoslovakia and the consideration of security risks, this intention was abandoned. The time of putting into operation of the metro protection system depends on the type of emergency. In case of a war conflict, the commissioning is spread over several days, because it is planned to gradually declare crisis situations. On the other hand, in the case of a storm wave from the Vltava cascade, it is desirable to get it up to speed as quickly as possible, and this is possible within six hours after the train runs have ended.

\section{Model situations, subway incidents and measures}

\section{Fires}

Subway fires can be caused by both human negligence, intention and technical malfunction. In the past, the most famous cases of fires in the Moscow and London Underground. Fires did not escape the Prague metro. There were several fires in Prague, most often as a result of a short circuit in the power line, ignition of the wiring or malfunction of the car lighting fuse. In no case, however, was there any loss of life or injury. From 1981 to 2001, there were nine fires. As for the Prague metro, fires were mainly due to the imperfect wiring of unreliable Russian wagons. In connection with this, in 1994 the government acted and approved the reconstruction of the wagons in order to improve the wiring of the trains. Since then, the Russian cars have been reliable.

\section{Large fire in the London Underground}

A major fire at King's Cross on 18 November 1987 led to a re-evaluation and tightening of fire safety measures. Human negligence in the form of a discarded cigarette or match was responsible for the burst of dust and garbage under wooden escalators. Subsequently, a large fire arose, which was exacerbated by the explosion and spread of the fire. Moreover, the incident occurred at peak hours in the evening and at the busiest station. Many passengers were trapped in the station because of the flames. More than 150 firefighters intervened and the fire was brought under control in two and a half hours. The unfortunate event did not go without victims, both in the ranks of passengers and on the side of intervening firefighters. The final number was 31 victims. Ironically, smoking in the subway was banned after a similar incident in 1984 when it burned at the Oxford Circus tube station. However, some passengers have ignored the ban and lit cigarettes already on escalators. [9] Despite all precautions, fires cannot always be wholly prevented, as shown by a fire in the Holborn Metro Station last April as a result of an electrical defect. [10] extinguished after more than 36 hours, 5000 people had to be evacuated. [11] 
After the 1987 event, the escalators were replaced with non-combustible metal and other measures were taken. [12] The current fire measures include a system that automatically activates in the event of a fire and fire department informs the fire brigade, public warning system, all parts of the station must be kept clean, for the combustible waste there is a designated area in the station and it is separated from other parts, the station must be made of materials of limited flammability, personnel training etc.

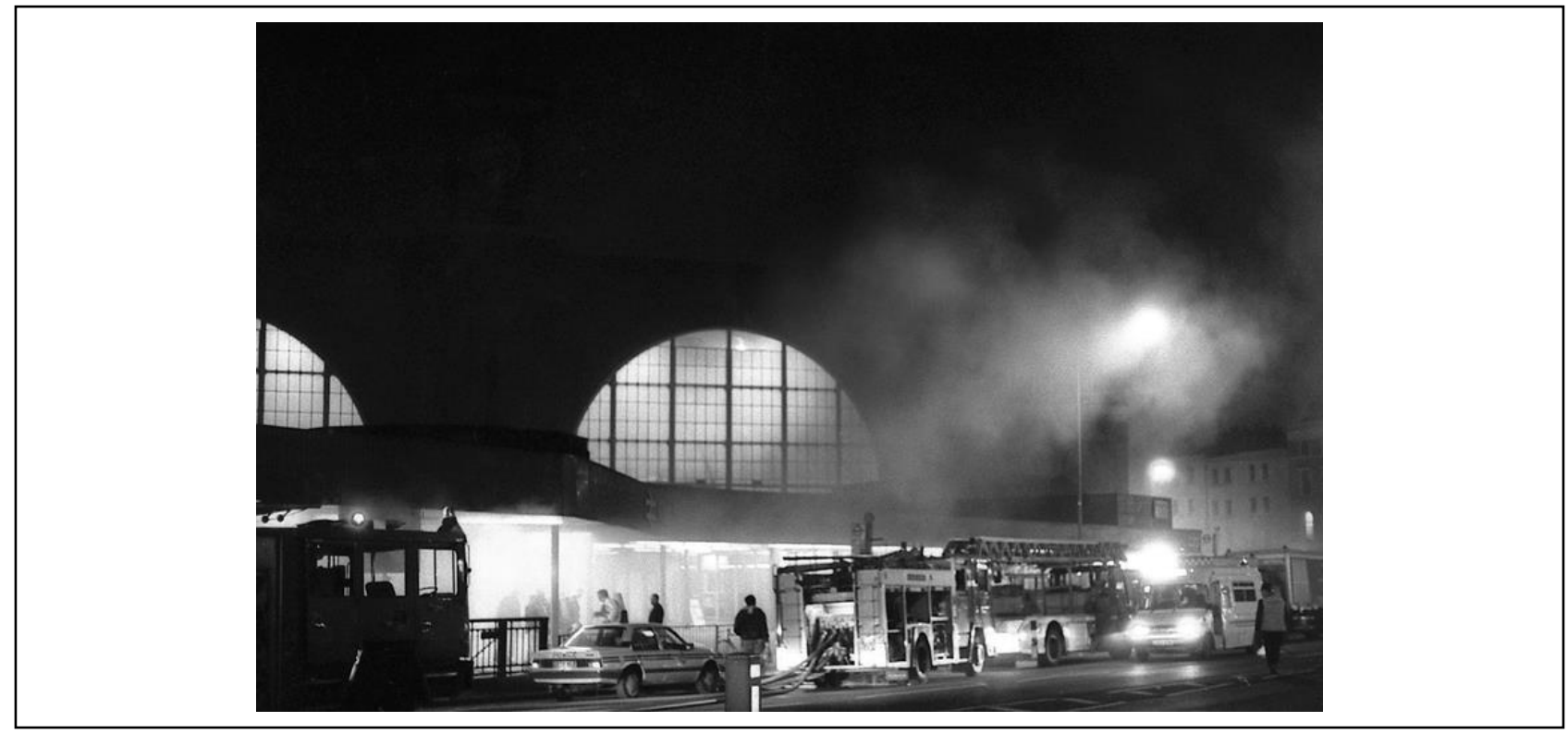

Fig. 1. Fire at King's Cross Station in London.

\section{Fire-fighting measures}

Current measures in the subway to prevent, or at least mitigate the effects of fires include, for example, a system that automatically activates in the event of a fire and informs the fire brigade of the occurrence of a fire. Another measure is the public warning system, the obligation to keep all parts of the station clean, the combustible waste is designated in the station reserved area and it is separated from the other parts, in addition, the station must be of materials of limited flammability smoke. [13]

Today, metro systems around the world are commonly equipped with CCTV systems. For early detection of fire, cameras can be equipped with fire video smoke detection capabilities. The camera is able to detect even a small amount of smoke in the video image. It then warns users of the system by alerting them to a computer monitor. In the Prague metro, CCTV monitors platform parts and escalators, their primary function being to monitor the flow of traffic. Only the camera recordings that are transmitted to the control room are stored, the rest are not, there are no financial means.

\section{Floods}

Floods are a threat from which the metro system must be protected. In the past, they had to face floods, for example, in Japan, specifically in the Tokyo subway, or even in New York. The Prague metro was hit by the worst floods in 2002, when a large number of stations were flooded and subsequent repairs and restoration were very expensive. 
Blahova, M. \& Zimek, O.: Protection of Places with High Concentration of People: ...

\section{Floods in the Prague metro}

The most devastating floods with regard to the Prague metro took place in August 2002. On Thursday, August 8, 2002 in the evening, at exactly 20:30, the 2nd flood level was declared.

A few days later on Monday, August 12, 2002, operation without restrictions was ensured for the time being, but construction of flood walls between the Vltava River and the Nádraží Holešovice station started to prevent the penetration of 100-year-old water. At 11:00 the third level of flood activity was announced and the implementation of flood protection measures started.

It is slightly surprising that the flood plans of the City of Prague and the Prague Public Transit Co. do not match the list of endangered stations. In the flood plan $\mathrm{Hl}$. The following stations were considered as endangered stations: Staroměstská, Křižíkova, Florenc - B, Smíchovské nádraží, Vltavská, Invalidovna and Palmovka.

Upon reaching the 3rd degree of flood activity, the closure of these endangered stations was expected. On the other hand, the flood plan of the Prague Public Transit Co. Inc. The City of Prague defined other stations as endangered, namely Nádraží Holešovice, Malostranská, Křřžíkova, Invalidovna, Palmovka, Florenc - B and Florenc - C. [14]

On Monday, August 12, 2002 from 13:15 to 16:45, the construction of flood protection barriers and closing of pressure closures of ventilation shafts took place. Among the first stations where flood barriers were built were stations of line B: Palmovka, Invalidovna, Křižíkova and Florenc. Then the pressure closures were closed in the ventilation shafts between the stations Staroměstská and Malostranská and at Nádraží Holešovice. Flood patrols on individual metro lines were also identified.

The last trains on 12 August 2002 with passengers in both directions in the section Florenc - C and Nádraží Holešovice passed at 22:45:48 and 22:47:00. Subway transport in this section was then terminated and replaced by bus service. Shortly after the last subway ride, at 11:11 pm, the evacuation of workers from Nádraží Holešovice and Vltavská stations was ordered.

At 23:20 firefighters went to Nádraží Holešovice station to drain water from flooded rooms of short-circuiting devices. On line B, the last passenger train at Křižíkova station stopped at 23:56:24. Then the Křižíkova station, the eastern vestibule on Palmovka, the Těšnov vestibule of the Florenc - $\mathrm{C}$ station and the direct exit from the Florenc - B.109 station were closed. [14] 


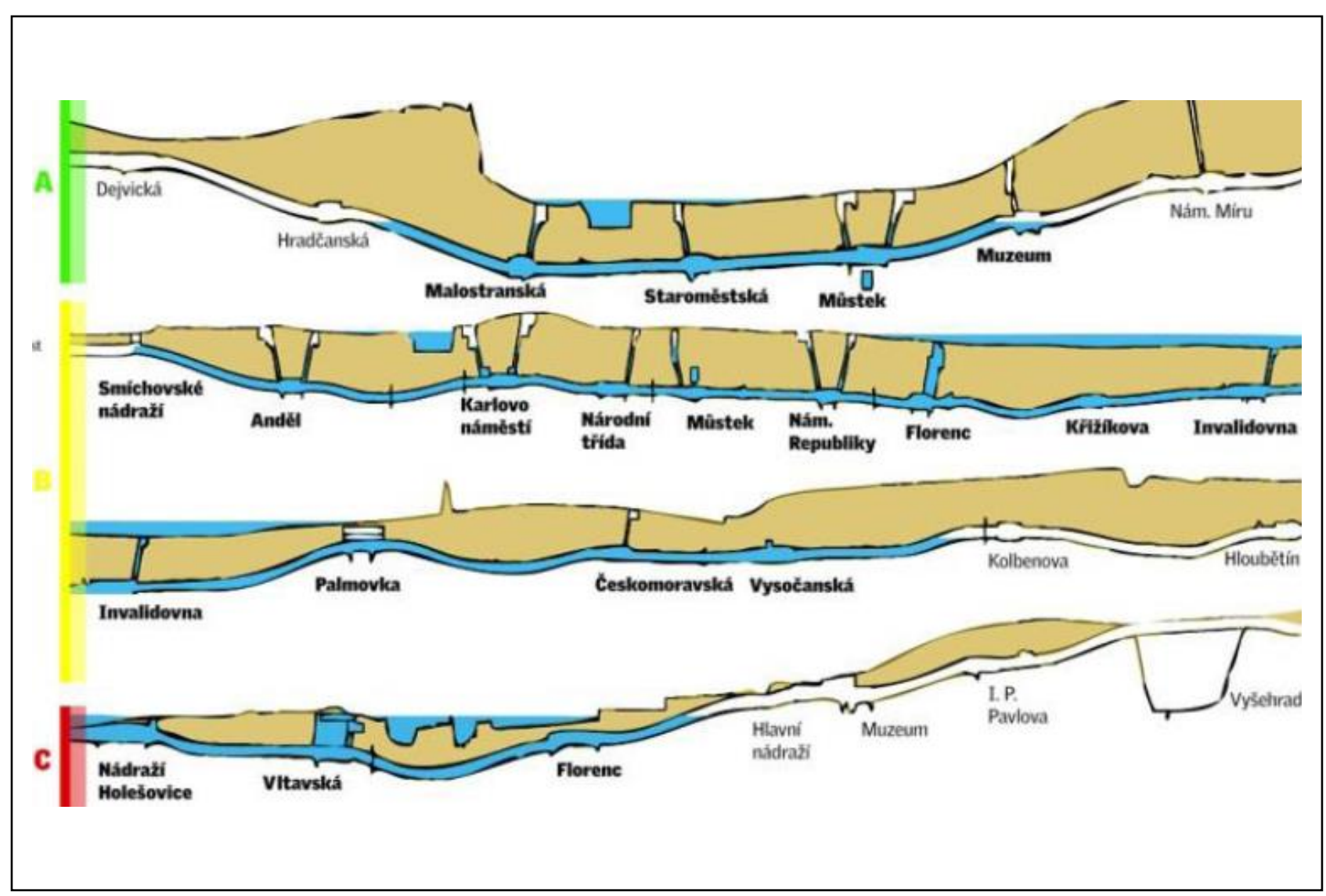

Fig. 2. Floods 2002 - flooded stations

\section{Flood protection measures}

Given that the metro area is also intended to serve as a civil protection facility for the evacuation and shelter of the population, the issue of subway security is essential. Some metro lines are built under the river and therefore have to face strong pressure and stress. Some measures have been improved following the devastating floods of 2002, when several stations and trains were flooded and new or improved existing measures were taken.

The problem of leakage water is thus solved by gas closures, the water is drained by a drainage trough located between the rails into collecting sumps. Each well contains a pair of pumps with automatic operation. The operation of the sump depends on the water level. In order to prevent damage as much as possible and best, the operation and failure of the pumps or the overflow of the sump are controlled by the technological control room.

Concerning the Prague metro, after the floods of 2002, the so-called metro flood protection principles were developed based on new experience. Many modifications have been made, the main endeavor is to prevent water from penetrating into the underground space by $60 \mathrm{~cm}$ higher than in August 2002. Protection is divided into primary and secondary. Secondary protection is represented by pressure seals. elements of metro protection system. The elements will be activated at the time of the flood and will provide protection in the event of a primary protection violation or water spill. Others are measures to prevent deformation of subway structures caused by hydrostatic pressure and buoyancy. [15] 


\section{Terrorist attacks, physical attacks}

Of the past, the most well-known are the terrorist attacks on the Tokyo subway and the Moscow and London subway bombs. Fortunately, terrorist attacks avoided the Prague metro, but several incidents occurred when one passenger attacked the knife of the other, etc. Terrorist attacks are very difficult to prevent, both because of the huge concentration of people in the vestibules of the metro and secondly, security measures are too expensive and some difficult realizable.

\section{Terrorist attacks in the Tokyo subway}

The Sarin attack of the Om Shinrikyo sect can be considered the first case of a subterranean terrorist attack. It was committed in the morning rush on March 20, 1995 by five members of the Om Shinrikjo sect. They set up plastic capsules filled with 900 $\mathrm{ml}$ of liquid sarin in three-line metro trains. To make the capsules look more subtle, they wrapped them in newspapers, laid them down on the ground, and punctured the tip of the umbrella at the designated stations. [16] In a few minutes, passengers experienced health problems in the form of eye pain and pressure, severe headaches, difficulty breathing and severe convulsions. Sarin damages the respiratory organs and central nervous system, respiratory muscles are paralyzed, leading to death. The sarin attack resulted in 13 dead and 5,500 poisoned persons.

Less than 10 liters of sarin were produced by a religious sect to attack the Tokyo subway. Due to the amount of impurities, however, it was a poor quality product, resulting in the death of hundreds or thousands of passengers. A police investigation found that it was about $30 \%$ sarin. Up to $97 \%$ sarin can be achieved by thorough purification.

The first attack report was received by the control center at 8:09 am from Tsukiji Station. Within an hour, the number of attacked stations climbed to 15. At all stations, medical staff intervened, totaling 1,364 and 131 ambulances. The Fire Rescue Service was unable to coordinate communication, which resulted in the loss of contact with the doctor at the emergency services dispatching center. There is a significant limitation to this problem, since professional first aid can only be performed with the consent of the physician. It was therefore necessary to contact a physician at the Tokyo Emergency Management Center for each operation.

As a result, all seriously injured patients were provided with all necessary care only in hospitals. There was no decontamination of the patients on site. The police closed the entrances to the attacked metro stations within an hour of reporting the attack, samples of the substance were taken and analyzed. After two hours the analysis resulted in a mistakenly dangerous substance acetonitrile. At around 11:00, sarin was finally correctly identified. It is somewhat astonishing that the results of the analysis did not come to the attention of the fire brigade and hospital staff until 11:00 am from television broadcasts.

\section{Terrorist attacks on the London Underground}

The London Underground was the target of suicide terrorist attacks on July 7, 2005, resulting in a total of 52 dead passengers and hundreds injured. 
The attackers were four, Shezzad Tanweer, Mohammad Sidique Khan, Jermaine Lindsay and Hasib Hussain, aged 18 to 30 . All but Jermaine Lindsay were born in Great Britain to Pakistani immigrants. Three terrorists detonated in the subway, the last and youngest of them, eighteen-year-old Hussain, on a double-decker bus. They used home-made organic peroxide-based explosive devices stored in their backpack. [17] All three explosions in the subway occurred just before 08:50 in the morning. The first explosion at Edgware Road station killed 6 people, another 163 were injured. A second attacker detonated between Aldgate and Liverpool Street, killing 7 passengers and injuring 171 passengers. The third explosion was the most deadly one, on the line between King's Cross and Russell Square, with 26 deaths and 340 injuries. Near King's Cross on Tavistock Square, the last striker fired. But it happened an hour after the explosions in the subway. In an explosion on a double-decker bus, he killed 13 passengers, injured at least another 110. [18] Originally, the fourth terrorist was in King's Cross subway station, captured on cameras. Later it was found that at 08:55 he tried unsuccessfully to contact his three accomplices. [19]

At a presentation of 5 May 2006, Mr Stuart Goodwin, United Kingdom Police Liaison Officer, presented the investigation. Shortly after the attacks, a missing persons reporting line was put into operation. The search for the crime scene took place under difficult conditions, because the tunnels were extremely hot, the rats were carrying parts of the bodies of dead passengers. All of this took a day and a half, after which the sets were packed and picked up from the tunnel. An essential role in the investigation was played by a large-scale camera system, accounting for about $20 \%$ of all street cameras in the world. The first clues led to a person named Khan, and on the missing persons reporting line reported the family of a lost son who had just traveled to London with Khan. A group of four suspicious men was recorded on the cameras, and later their car and the apartment in Leeds where the bombs were produced were tracked down. Subsequently, their journey from Leeds to the subway where they split up was reconstructed. One of the perpetrators was unable to get to the subway because of congestion, panicked, walked the streets for tens of minutes, as detected by a camera system, then got on the bus and activated the explosive there. If he opted for an explosion in the vestibule in the queue of turnstiles, the death toll would be many times higher. [20]

\section{Physical attacks}

In addition to terrorist attacks, we encounter perpetrators in metro around the world, who threaten their behavior and physically attack other passengers. Similar incidents occurred in Prague and London, for example. On the London Underground at Leytonstone Station in December 2015 at around 8:00 pm, a man attacked another passenger and caused serious injuries. Another two people slightly injured. Shortly after the attack, the perpetrator managed to detain. [21]

A similar case of knife attack occurred in March 2015 in the morning when a 21-year-old Slovak attacked another passenger at the Invalidovna station and caused him very serious neck injuries. He chose his victim at random. Against another assailant, police had to intervene quite recently at Karlovo namesti metro station on the 
night of December 22, 2015. A drunk and drugged, very aggressive man threatened other passengers with a knife.

Relatively media-known is the attempted murder at Kačerov Station in July 2014. The offender attacked his former wife, who is employed as a turnstile guard and broke into the control room. To assist the assaulted woman, an employee of the Transport Company rushed and was finally stabbed in the stomach with a kitchen knife. Thanks to the summoned help, the man survived. [22]

The tragic end had an assault on policeman Ján Mat on August 2, 2002, a midshipman serving in the Metro Department. Prior to 18:00 at the Museum station, the perpetrator Alexander Kručinin threw an unknown explosive under the wheels of the train arriving at the station and stabbed a homemade made lance of pensioner Milan Vítek. Jan Mato and his colleague, a two-man patrol of police officers, came through the panicked crowd first. The offender attacked the police officer with his improvised lance weapon and stabbed him several times in the chest. John Mato succumbed to his injuries before he could summon. [23] Alexander Kručinin committed suicide by hanging in custody. [24]

\section{Security precautions}

Securing the metro is very difficult, safety measures will never be sufficient. After the terrorist attacks on September 11, 2001 in New York, all waste bins were prevented from the Prague metro. Nine years later, the baskets returned to the subway with the only difference that they were special counter-terrorism baskets of Israeli production. Magistrát hl. The City of Prague bought 90 pieces, one of which is worth 87 thousand CZK. These baskets are strategically located at the stations with the highest concentration of people - ie. transfer station and city center. The baskets are very sturdy, one weighing over $400 \mathrm{~kg}$ and consists of two steel shells - inner and outer. This prevents the blast wave from spreading to the sides, but instead directs it into the ceiling and the basket does not fall apart. [25] Some cities, such as Washington, are so far away that their baskets are able to detect the luggage substance through sensors to detect whether it is an explosive.

\section{Accidents, derailment of the metro}

Probably the most famous recent accident is the derailment of the Moscow Metro in 2014. The metro derailed in Prague in the past as well, but the accident did not have the same tragic consequences as the derailed metro in Moscow. The Prague train derailed on November 21, 2005 during a test run on the test track. It was a new set of Siemens M1, which passed through the signal, end rail stop and fence. No one was injured in the accident. The reason for derailment was the driver's failure to keep speed and instead of $60 \mathrm{~km} / \mathrm{h}$ was driving $80 \mathrm{~km} / \mathrm{h}$. Although the automatic braking system braked the train, the speed was exceeded too much and the train was only braked. [26]

\section{Metro derailment in Moscow}

The Moscow metro accident of July 15, 2014 is one of the worst that happened here. In the morning rush hour at 8:39 local time, three metro cars derailed. It was a stretch 
between Slavjanskij bulvar and Pobědy Park. [27] 24 people died in the accident and another 162 were injured, some of them seriously. The work of rescuers and firefighters was particularly hampered by the fact that the accident occurred at the deepest metro station in Moscow at a depth of 84 meters below the ground. [28] The rescue work was not completed until the following morning. The fault of derailment was the wrong handling of the switch. The day after the event, the maintenance master and his deputies were arrested, who were in charge of installing the switch that took place in May. They were accused of breaking the security rules. [29]

\section{Seoul subway line collision}

Two subway trains collided in the South Korean capital at a subway station on May 2, 2014 at 2pm. The reason for stopping the first set was technical problems, the second set then hit it in the tunnel from behind. One of the wagons derailed after the impact. Several dozen passengers were injured in the accident, the exact numbers of the injured vary depending on the sources, some talking about 78 to 170. [30] Nobody died in the accident. Some passengers, however, disobeyed the calls to wait in the trains and forcibly open the doors of the train and leap out. About a thousand passengers had to be evacuated. The reason for the accident was a fault in the signaling. [31]

\section{Security precautions}

The question arises as to whether a similar situation could also occur in the Prague metro. The Prague Public Transit Co. is trying to minimize this risk as all lines are regularly checked and maintained. Latch tests of switches are carried out every day, defectoscopic inspections and measurements are scheduled on a regular basis. In addition, the Prague metro is more modern and more modern are the security facilities. Part of the Soviet trains were gradually replaced by new ones, some old trains underwent a complete reconstruction. As far as electrical and safety equipment is concerned, harmful and flammable materials have been removed. However, of course, it is not possible to rule out a similar accident $100 \%$. In this case, rescue service exercises are regularly carried out. [32]

\section{Security measures and their comparison}

No security measure is $100 \%$, there is a weakness everywhere, be it turnstiles, human factor, station itself and the material used in their construction, station locations not covered by security cameras, information available about the metro system, its security, As already mentioned at the beginning of subchapter 5.4, the metro system is very difficult to secure and protect against terrorist attacks. Terrorism experts agree on this. Libor Lochman, director of the anti-terrorist police unit, is of the opinion that metro protection is almost impracticable. There are plenty of ways to protect the metro as much as possible. In Washington, baskets are installed in stations that have the ability to detect explosives. However, these are somewhat unnecessary if the explosive device is stored elsewhere than in the basket. Turnstiles at subway entrances can be fitted with safety frames, but the attacker does not even have to pass through them to commit the attack. 
All he had to do was put his bag of explosives in the crowd, which no one would notice and then detonate. In the Prague subway, dispatchers are obliged to monitor whether any of the passengers has put a suspicious bag or other object in the vestibule, but bringing the bomb into the metro does not prevent it.

Other security measures could be introduced in the Prague metro, such as the Washington Metro, which is considered one of the best secure metro systems in the world. Washington Metro is equipped with both chemical and biological sensors, specially trained bomb-hunting dogs, explosives detectors, and clever waste bins to detect explosives stored in them. There are also special police units in the Washington subway, which are also on the Prague subway, but those in Washington are able to intervene within five minutes of the incident. The problem of Dopravní podnik hl. However, the City of Prague is where to get funds for the implementation of these measures. The transport company does not have enough resources for such costly measures, one chemical detector costs some millions of dollars. [32] Even the security cameras placed in the vestibules of the Prague metro are not primarily intended for protection against terrorist attack, but only for monitoring station traffic and monitoring places where passengers are most at risk, such as escalators.

\section{Conclusion}

The aim of the article was to create the most comprehensive material with an overview of various types of risks and related safety measures applied in metro systems in the Czech Republic and abroad and current trends in security. This goal was achieved. After studying the available sources and literature I can state that the security of the metro system in Prague is at a very good level, although some types of security measures are not applied. Furthermore, I discussed the individual risks that may occur in the subway, whether of natural origin or human factor. At the same time, I proposed measures to avoid these risks, or at least to eliminate possible damage to health and property to the lowest possible level.

\section{Acknowledgements}

This research was based on the support of the Internal Grant Agency of Tomas Bata University in Zlín, the IGA / FAI / 2019/003 project and the Institute of Safety Engineering, Faculty of Applied Informatics.

\section{References}

[http://www.mapametra.cz/londyn/ (2013). London Underground map. Metro map. Accessed on: 2016-02-06.

https://en.wikipedia.org/wiki/Platform_screen_doors\#United_Kingdom

(2016).

Platform screen doors. United Kingdom. Wikipedia. Accessed on: 2016-02-07.

http://www.discoverfrance.net/France/Paris/Paris_metro.shtml (2016). The Paris

Metro, Part 1. Discover France! Accessed on: 2016-02-08. 
Guryča, R. (2013). Metro in New York: Queen of Underground, nearly 400 km long. Available from: http://www.stoplusjednicka.cz/metro-v-new-yorku-kralovnapodzemi. 100+1. Accessed on: 2016-02-08Guryča, R. (2013). Metro v New Yorku: Královna podzemí s délkou skoro $400 \mathrm{~km}$.

Švestka, J. \& Cikán, T. (2015). City below the city: New York's subway has 34 lines and a safety ,dead man's switch“. Available from: https://www.novinky.cz/cestovani/exotika-a-amerika/clanek/mesto-pod-mestemnewyorske-metro-ma-34-linek-a-bezpecnostni-pojistku-mrtveho-muze-325819. Novinky.cz. Accessed on: 2016-02-08. https://www.hzscr.cz/clanek/hzs-hlavniho-mesta-prahy-menu-ochrana-obyvatelstvaukryti-ukryti.aspx. (2015) Hiding. Fire Rescue Service of the Czech Republic. Accessed on: 2017-05-01.

https://www.metroweb.cz/metro/osm.htm (2017). Metro protection system (OSM). Metroweb. Accessed on: 2017-05-01. http://pepikov.cz/?p=253 (2017). Anti-nuclear Prague. Pepíkov. Accessed on: 2017-05-01. http://news.bbc.co.uk/onthisday/hi/dates/stories/november/18/newsid_2519000/2519 675.stm (2008). 1987: King's Cross station fire 'kills 27`. BBC. Accessed on: 201602-07.

https://www.bbc.com/news/uk-england-london-32231725 (2015). Hollborn undergroud fire: Electrical fault caused 36-hour blaze. BBC News. Accessed on: 201602-07.

https://www.bbc.com/news/uk-england-london-32173689 (2015). Holborn underground fire extinguished. BBC News. Accessed on: 2017-04-29.

Saul, H. (2015). Holborn fire: Underground blaze is finally extinguished after causing two days of chaos. Available from: https://www.independent.co.uk/news/uk/homenews/holborn-fire-underground-blaze-is-finally-extinguished-after-causing-two-daysof-chaos-10154245.html. Independent. Accessed on: 2017-04-29.

https://www.gov.uk/government/uploads/system/uploads/attachment_data/file/15114/ subsurfacerailsafety.pdf (2005). Regulatory reform (Fire safety). Order 2005. Gov.uk. Accessed on: 2016-02-07.

https://www.metroweb.cz/ (2017). Metroweb. Accessed on: 2017-04-29.

Kabátová, B. (2012). Jan Cibulka: Worse than stopping the metro was managing the chaos on the surface. Available from: https://www.denik.cz/povodne_02/horsi-nezzastavit-metro-bylo-zvladnout-chaos-na-povrchu-20120807.html Deník.cz. Accessed on: 2016-03-05.

https://www.metroweb.cz/povoden/povoden-opatreni.htm (2017). Flood protection of Prague metro. Metroweb. Accessed on: 2017-04-29.

https://en.wikipedia.org/wiki/7_July_2005_London_bombings (2016). 7 July 2005 London bombings. Wikipedia. Accessed on: 2016-02-23.

https://www.bbc.com/news/uk-33253598 (2015). 7 July London bombings: What happened that day? BBC News. Accessed on: 2016-02-23.

Agency (2015). 7/7 bombings timeline: How the day unfolded. Available from: https://www.independent.co.uk/news/uk/home-news/77-bombings-londonanniversary-live-timeline-how-the-day-unfolded-10369476.html. Independent. Accessed on: 2016-02-23. 
Blahova, M. \& Zimek, O.: Protection of Places with High Concentration of People: ...

ČTK (2015). A man with a knife raged in the Prague metro, the police had to tame him with a taser. Available from: https://zpravy.aktualne.cz/regiony/praha/zdrogovany-aopily-vytrznik-radil-v-metru-policie-ho-

musela/r dee07626a8be11e5a405002590604f2e/. Aktuálně.cz. Accessed on: 201602-23.

https://www.policista.cz/clanky/reportaz/nezapomeneme-jan-mato-1059/ (2014). WE WILL NOT FORGET: Ján Mato. Policista.cz. Accessed on: 2017-05-24.

Prochazkova, D.; Prochazka, J.; Rusko, M.; Mikulova, M. \& Ilko, J. (2017). Model for Critical Infrastructure Safety Management, Proceedings of the 28th DAAAM International Symposium, pp. 0602-0610, B. Katalinic (Ed.), Published by DAAAM International, ISBN 978-3-902734-11-2, ISSN 1726-9679, Vienna, Austria

Lidovky.cz \& ČTK (2009). The Prague metro will have anti-terror baskets from Israel. Available at: https://www.lidovky.cz/byznys/doprava/prazske-metro-bude-mitprotiteroristicke-kose-z-izraele.A091211_120813_ln-doprava_mev. Lidovky.cz. Accessed on: 2017-05-24.

https://www.pozary.cz/clanek/4234-vykolejena-souprava-metra-siemens-m1/ (2005). Derailed Siemens M1 metro train unit... Požáry.cz. Accessed on: 2017-04-29.

Korablinov, A. (2014). 21 dead, scores injured after Moscow mero coaches derail. Available

from:

https://www.rbth.com/society/2014/07/15/10_dead_scores_injured_after_moscow_m etro_coaches_derail_36703. Russia Beyond. Accessed on: 2017-04-01.

Lidovky.cz \& ČTK (2014). The worst crash in history. The tragedy in Moscow has 22 victims. Available from: https://www.lidovky.cz/svet/tragedie-v-moskve-ma-22obeti-chatrajici-metro-je-nebezpecne.A140716_101145_ln_zahranici_msl.

Lidovky.cz. Accessed on: 2017-04-01.

https://cs.wikipedia.org/wiki/Vykolejení_vlaku_moskevského_metra_2014 2014 Moscow Metro derailment. Wikipedia. Accessed on: 2017-04-01.

ČTK, Novotná, P. \& kap (2014). At least 170 people were injured in the collision of two metro trains in Seoul. Available at: https://www.irozhlas.cz/node/5926549. iRozhlas.cz. Accessed on: 2016-03-07.

věž (2014). In Korea, two subway trains collided, dozens injured. Available from: https://www.idnes.cz/zpravy/zahranicni/v-jihokorejskem-soulu-se-srazily-dva-vlakymetra.A140502_100754_zahranicni_vez. iDnes.cz. Accessed on: 2016-03-07.

sk (2014). Could the metro derail in Prague? Impossible, we check the tracks, says the expert. Available from: https://www.lidovky.cz/domov/vykolejeni-soupravy-jako-vrusku-mame-modernejsi-metro-rika-dopravni-

expert.A140716_142034_ln_domov_sk. Lidovky.cz. Accessed on: 2017-04-29. Hejl, J. (2014). The difference between the metro in Prague and Moscow? Mainly in modernization. Available from: https://zpravy.aktualne.cz/domaci/prazske-metro-jena-tom-dobre-lepe-nez-to-v-moskve/r 02d93af00da111e4a54c0025900fea04/.

Aktuálně.cz. Accessed on: 2017-04-29.

MF DNES, jav, gag \& luh (2004). It is almost impossible to protect the metro, experts say. Available from: https://www.idnes.cz/zpravy/zahranicni/ochranit-metro-je-temernemozne-soudi-odbornici.A040206_222244_zahranicni_fri. iDnes.cz. Accessed on: 2016-02-28. 